\title{
Foreign Direct Investments and Economic Growth in Sub-Saharan African Countries: A Comparative Analysis between Landlocked Countries and Countries Having Access to the Sea
}

\author{
Luc Nembot Ndeffo ${ }^{1}$, David Kamdem ${ }^{1} \&$ Roger Tsafack Nanfosso ${ }^{2}$ \\ ${ }^{1}$ Faculty of Economics and Management, University of Dschang, Cameroon \\ ${ }^{2}$ Faculty of Economics and Management, University of Yaoundé II-Soa, Cameroon \\ Correspondence: Luc Nembot Ndeffo, Faculty of Economics and Management, University of Dschang, P. O. \\ BOX 110, Cameroon. Tel: 237-77-635-731. E-mail: ndefluc@yahoo.fr
}

Received: February 20, 2013

Accepted: April 16, 2013

Online Published: May 21, 2013

doi:10.5539/ijef.v5n6p157

URL: http://dx.doi.org/10.5539/ijef.v5n6p157

\begin{abstract}
Institutional reforms implemented since the beginning of the Nineties resulted in a substantial increase in Foreign Direct Investments (FDI) inflow into Sub-Saharan Africa. The present study uses data on 32 countries to evaluate the impact of FDI on economic growth through panel data regressions for the period 1988-2008. The study captures the incidence of commercial openness through a comparison between the landlocked countries and those having access to the sea. The results show that FDI have a positive and significant effect on economic growth in countries that have access to the sea whereas for the landlocked countries, the results are not significant. It is therefore recommended that African countries continue to implement policies favorable to the attraction of FDI. Landlocked countries should lay a particular emphasis on the construction of infrastructures (roads, railways, airports, and phone) that facilitate the flow of goods towards the different ports for shipment to countries where their goods are more demanded.
\end{abstract}

Keywords: foreign direct investments, economic growth, landlocked countries, Sub-Saharan Africa

\section{Introduction}

The lack of resources necessary to the financing of investments constitutes one of the obstacles to the economic development of the African continent. The first strategies of the leaders focused on development aid and the public debt. However, numerous studies show that development aid did not have the awaited impact on the economic growth and development of these countries. The debt crisis of the beginning of the 80 s forced many States to carry out successive rescheduling of the debt which by increasing the interest paid contributed to the deterioration of their balance of payments. Strategies attracting foreign direct investment (FDI) would be indispensable to raise the rate of investment in Africa. This is why one of the challenges of the New Partnership for African Development (NEPAD) of the African union is based on the mobilization of financial resources to realize massive investments and catch up with the development gap of the continent in relation to the other regions of the world. To achieve this, NEPAD intends to wipe out the perception of Africa by the investors as being a "high risk" continent because of the insecurity of property rights and the insufficiencies of the law. Several studies show that the impact of the FDIs on growth and well-being in Sub-Saharan Africa remains mitigated. Cockcroft and Riddel (1991) show that during the 80s, the contribution of FDI to production remained small in many African countries. Other works conclude that FDIs only brought a modest contribution in terms of creation of jobs in Africa (Nzomo, 1971) or in terms of transfer of expertise in management (Kim, 1985). It is necessary to note however that these studies are old and were carried out at a time when the economic policies in Africa were characterized by strong distortions. Some more recent works show that the positive impact of multinationals on development depends on the conditions in which the investments are done. The maximization of the gains of FDIs in a country requires macroeconomic stability, international trade strategies that encourage exports, a liberal economic policy encouraging competition and the setting up of strategies that encourage the inflow of FDIs (Pigato, 2000). For investments to be more efficient, it is necessary that more effective communication networks and infrastructures are put in place to enable industries to achieve economies of scale and minimize costs, and hence increase the contribution of FDIs to development (Moran, 1999). It is in this light 
that since the beginning of the $90 \mathrm{~s}$, reforms are put in place to attract FDIs toward the African continent (CNUCED; 1999). The combined effects of this reform, the actions of NEPAD and the irreversible process of globalization, encouraged the growth of FDI inflow to this continent during the last decades. The volume of FDI toward Sub-Saharan Africa doubled between the period 1982-1989 and the period 1990-1995 (Bosworth and Collins 1995). According to the statistics of the World Development Indicators of the World Bank and from IMF (2011) report, the inflow of FDI toward the countries retained in the present survey went from 4818,3 million US dollars in 2000 to 8935,1 million US dollars in 2005 and reached a record level worth 25787,4 million dollars in 2009. The objective of this study is to appreciate the impact of FDI on the economic growth of Sub-Saharan African countries. How do FDIs affect the indicators of growth in these countries? Does the impact of FDI on the economic growth in Sub-Saharan Africa vary depending on whether the countries are landlocked or that they have access to the sea? The present study on 32 Sub-Saharan African countries appreciates the impact of FDIs on economic growth through the use of panel data regressions for the period 1988-2008. It makes a comparative analysis between the results of landlocked countries and those of the countries having access to the sea. Section 2 gives a state of the literature on the relationship between FDIs and economic growth. Section 3 presents the methodology used whereas the results of the study are presented in section 4 . The last section presents the findings and recommendations.

\section{Literature Review}

The literature review includes the theoretical aspects as well as the empirical ones.

\subsection{Review of Theoretical Works}

It is dedicated to a brief presentation of the evolution of economic growth models. Indeed, the models of neoclassic growth of Solow (1956), Swan (1956) as well as the models of endogenous growth, developed by Romer (1986) and Lucas (1988) present themselves as the theoretical setting permitting to study the relation between FDI, development of physical capital, development of human capital and economic growth. The model of Solow and Swan puts in place a neoclassical shape of the production function that postulates that:

- the returns are decreasing in relation to every factor of production;

- the returns to scale are constants;

- the elasticity of substitution between factors of production is positive and continuous;

- by hypothesis, the rate of savings is constant.

The endogenous growth model is constructed from a certain number of criticisms addressed to the neoclassical growth model of Solow and Swan. On the basis of these criticisms, the first steps towards the theory of endogenous growth that makes the following assumptions have been set:

- the endogenous growth model considers technical progress as an endogenous factor of growth;

- in the models of endogenous growth, the factors of production present positive externalities;

- economic growth is the consequence of the accumulation of physical capital. Therefore, the increasing returns constitute its foundation;

- the supporters of the endogenous growth show that the investments achieved by the state in the infrastructures facilitate the circulation of information, people and goods (Barro, 1990) and improve the productivity of firms;

- economic growth also depends on innovation that results from research and development developed by Romer (1990) who underlines the fact that growth is linked to the increases and the diversification of inputs.

By introducing the accumulation of human capital in the growth function, Lucas (1988) distinguishes the voluntary capital that corresponds to the accumulation of the knowledge "schooling" from involuntary capital "learning by doing". He shows that the improvement of the level of training of every individual increases the stock of human capital of the country and improves the productivity of the economy. Several researchers participated in the development of the endogenous growth model. The complementarity of the different approaches led to the construction of a more complete model of endogenous growth. By introducing a flow of expenses G, which is considered a pure public good as a factor of production, Romer (1990) admits that the production function for every firm $i$ is:

$$
Y_{i}=A K_{i}^{\alpha} N_{i}^{1-\alpha} G^{1-\alpha}
$$

With $\mathrm{Yi}, \mathrm{Ki}$ and $\mathrm{Ni}$ being respectively output, the stock of private capital and the labour of the ith enterprise, $\mathrm{G}$ the spending of the state in infrastructures and A the level of technological advancement assumed to be constant in time. While supposing that the enterprises are identical, the social production function is written as follows: 


$$
Y=A K^{\alpha} N^{1-\alpha} G^{1-\alpha}
$$

The private factors of production $\mathrm{K}$ and $\mathrm{N}$ have constant returns. The public expenditure is constituted of the final good, with $\tau$ the fraction of the final product absorbed by the state. While supposing that the households dedicate a part of their income to the consumption of goods, the dynamics of accumulation of capital takes the form:

$$
\dot{K}=s(1-\tau) Y-\delta K
$$

Besides, the social production function is determined by replacing $\mathrm{G}$ with $\tau Y: Y=A K^{\alpha} N^{1-\alpha}(\tau Y)^{1-\alpha}$, which yields the function:

$$
Y=\tau^{\frac{1-\alpha}{\alpha}} A^{\frac{1}{\alpha}} N^{\frac{1-\alpha}{\alpha}} K
$$

Given that $\mathrm{A}, \mathrm{N}$ and $\tau$ are constant, we obtain the AK model. In the absence of demographic growth, equations (3) and (4) permit to express the growth rate of the stock of capital:

$$
g k=\frac{\dot{K}}{K}=s(1-\tau) \frac{Y}{K}-\delta=s(1-\tau) \tau^{\frac{1-\alpha}{\alpha}} A^{\frac{1}{\alpha}} N^{\frac{1-\alpha}{\alpha}}-\delta
$$

Since this rate is constant, growth is qualified as self-sustained (Schubert, 2000). The introduction of endogenous technical progress in the canonical models of growth is made by Romer (1990) and Aghion and Howitt (1992). Whereas Aghion and Howitt (1992) hold that new innovations drive old ones putting the economy in a process of "creative destruction", Romer (1990) holds that while accumulating, the innovations by their diversity constitute a source of wealth for the economy. His function of accumulation of technological capital is written as follows:

$$
\dot{A}=\rho N_{A} A
$$

With $\mathrm{N}_{\mathrm{A}}$ being the number of researchers, $\rho>0$ a parameter of the efficiency of research, and A, the technological capital. Romer supposes that the growth rate of the technological capital is a linear function of the number of researchers. The researcher's marginal productivity $\rho A$ increases with an increase in the existing capital. The hypothesis of the linearity in A of the function of technological capital leads to self-sustained growth (Schubert, 2000). While supposing that the proportion of researchers within the population is constant, we obtain:

$$
N_{A}=\frac{\alpha}{1+\alpha} N \text { and } N_{Y}=\frac{1}{1+\alpha} N
$$

With $N_{A}$ the quantity of the factor labor used. While supposing that the population is constant and economic growth takes place at an endogenous or constant rate, we have:

$$
g=\frac{\dot{A}}{A}=\frac{\dot{Y}}{Y}=\rho \frac{\alpha}{1-\alpha} N
$$

Since the activity of research remains determining for growth, the rate $\mathrm{g}$ increases with the efficiency of research. One of the more recent versions of the endogenous growth model is that of Borenztein et al. (1995) that goes from a Cobb-Douglass type production function:

$$
Y_{t}=A H{ }_{t}^{\alpha} K_{t}{ }^{1-\alpha}
$$

With A the exogenous technology factor, $\mathrm{H}$ the human capital, and $\mathrm{K}$ the physical capital. Let $\mathrm{N}$ be the total number of capital goods produced by two types of firrms (foreign firms and the domestic firms) in the economy, $\mathrm{n}$ stands for the goods produced by the domestic firms and $\mathrm{n} *$ stands for those of the foreign firms.

$$
\mathrm{N}=\mathrm{n}+\mathrm{n} *
$$

Suppose that the cost of technological adaptation of the domestic firms $\mathrm{F}$ has a negative correlation with the number of foreign businesses $\left(\mathrm{n}^{*}\right)$ operating in the host country. This is why Borensztein et al admit that FDI is the channel by which technological progress is transmitted. The functional form retained for $\mathrm{F}$ is:

$$
F=F\left(n^{\bullet}, N / N^{\bullet}\right), \text { where } \frac{\partial F}{\partial n^{\bullet}}<0 \text { and } \frac{\partial F}{\partial\left(N / N^{\bullet}\right)}<0
$$


To finalize the model, the authors suppose that individuals maximize the following standard function of inter temporal utility:

$$
\bigcup_{t}=\int_{t}^{\infty}{\frac{C_{s}}{1-\sigma}{ }^{1-\sigma}}^{-\rho(s-t)} d s
$$

Where $\mathrm{C}$ represents the number of units consumed of the final good Y. Given that the rate of return is (r), the optimal consumption path is given by the following condition:

$$
\frac{C_{t}}{C_{t}}=\frac{1}{\sigma}(r-\rho)
$$

One can verify easily that the growth rate of the consumption must, in a steady state, equal the rate of growth of output $g$.

$$
g=\frac{1}{\sigma}\left[\psi F(n \cdot N / N \cdot)^{-1} H-\rho\right]
$$

This equation shows that FDI, measured by $\mathrm{n} *$ reduces the cost of introduction of new varieties of capital goods, thus increasing the rate of introduction of these goods. Besides, Borenztein et al. (1995) admit that a positive correlation exists between the level of human development and the impact of FDI on economic growth. For an empirical verification, they estimated the following model:

$$
g=c_{o}+c_{1} F D I+c_{2} F D I x H+c_{3} H+c_{4} Y_{0}+c_{5} X
$$

This model, like many others has been the subject of many empirical tests.

\subsection{Empirical Literature Review}

FDI encourages the transfer of technology toward the host countries (Duming, 1993; Catin et al. 2002), promotes the development of the human capital (Toufik and Bouoiyour 2002), improves the rate of investment (Bosworth and Collins 1999) and commercial openness (Olakounlé, 2004). By transition, FDIs have a positive effect on the economic growth of the host countries. Numerous studies have investigated the impact of FDI flows on economic growth. Most of these studies were carried out in Asian and Latin-American countries given their economic performance and their strong capacity to attract foreign funds. Berthélémy and Démurger (2000) are interested in the impact of FDIs on the Chinese economy. They find a positive impact of FDIs on growth. The results of the study of Fung et al. (2002) on the same country show that FDI constitutes an important element of economic growth in China and confirm a positive correlation between foreign business investments and the GDP, both at the national and provincial levels. De Mello (1996), is interested in five countries of Latin America (Brazil, Chile, Colombia, Mexico, Venezuela). His study that uses time series reveals the positive impact of FDIs on economic growth. A more recent study carried out by Abdur and Mavrotes (2003) is interested in the direction of causality between FDI and growth in three countries which are part of the highest recipients of FDIs: Chile, Malaysia and Thailand. The comparative study covers the period (1969-2000) and uses the Toda-Yamamoto causality test. For Chile, FDI depends on the economic growth rate and not the reverse. For Malaysia and Thailand, the relation is bi-directional between economic growth and FDI. The cross sectional analysis of Blomström et al. (1994) shows a positive impact of FDI on the economic growth of developing countries having a relatively high income level. These results mean that the recipient countries should have a minimum level of development to benefit from the advantages of FDIs. Knôdler and Hauser (2001) are interested in the impact of FDI on economic growth in the Western regions of Germany. The results of the study show a positive and statistically significant correlation between economic growth and the growth of FDI. The regions benefitting from the intense activities of firms financed by FDIs have better prospects of growth and development. The study of Borenztein et al. (1995) follows the same logic. It focuses on 69 developing countries and covers two decades 1970-1979 and 1980-1989. Several sets of regressions are done. The results show that FDI triggers a side effect on human capital to contribute economic growth. The beneficial effects of FDIs on the global productivity of factors are only discerned for the countries having a minimum level of human capital. A similar study has been carried out by Nauro and Kinoshita (2002). It focuses on 25 countries of Central and Eastern Europe. These authors arrived at the same findings. The merit of these studies is to have tested the theoretical relationship between FDI, in combination with human capital and economic growth. The positive impact of FDI on growth does not always make unanimity. Some authors wonder about the interpretation made on the correlation between FDI and growth. Rodrik (1999) admits that the correlation is due to an inverse causality, insofar as FDIs move toward the most productive countries. Nair-Reichert and Weinhold (2001) underline that cross sectional analysis make unrealistic hypotheses on the homogeneity of the sample on the one hand and on 
the inability of the studies to test the causality of the FDI-growth relation on the other hand. As for Xiaoying and Xiaming (2005), they note that many authors do not carry out endogeneity tests between FDI and growth rate, given the interdependence between the two variables. That is why in their study which focuses on 84 countries on the period (1970-1999), they correct the limits that characterize the previous works. They test the endogeneity between FDI and growth, which allows them to choose a suitable estimation method. They introduce interactions between human capital, infrastructures and the technological gap to appreciate if FDI can affect growth in an isolated manner or through these interactions. Their results show that FDIs, not only affect growth directly, but also through these interactions. This methodology seemed pertinent to us and has been applied in the present study.

\section{Method}

The survey is about 32 countries of Sub-Saharan Africa for the period (1986-2006). To appreciate the impact of FDI on growth, regressions an carried out following the methodology of Xiaoying and Xiaming (2005) for its relevance to this study.

\subsection{Specification of the Economic Growth Equation}

We use an endogenous growth function including a technical progress factor and a human capital factor. It is specified as follows:

$$
T C P I B_{i, t}=\alpha_{i}+\beta_{i}^{\prime} X_{i, t}+\xi_{i, t}
$$

TCPIB $i, t$ is the growth rate of real GDP per capita of country i during the year $t$;

If $\alpha_{i} \in \mathrm{R}, \beta_{i}=\left(b_{1, i}, b_{2, i} \ldots \ldots \ldots \ldots \ldots \ldots b_{k, i}\right)^{\prime}$ a vector of the parameters.

and $X_{i, t}=\left(x_{1, i t}, x_{2, i t}, \ldots \ldots \ldots \ldots \ldots \ldots \ldots x_{k, i t}\right)^{\prime}$, the vector of the following k explanatory variables.

LOPPOP $i$,t: population logarithm of the country i during the year t;

IDO/PIB i,t: rate of domestic investment of the country i during the year $t$;

TSP $i$, t: rate of primary schooling of the country $i$ during the year $t$ which is a proxy of the human capital factor.

FDI/PIB i,t: ratio of FDI to GDP of country i during the year t;

INFLATION $i, t$ : rate of inflation of the country i during the year $t$;

OUVERTCOM i,t: rate of commercial openness of the country i during the year $t$;

EXCHANGE i,t: exchange rate in relation to the US dollar of country i during the year $t$;

CONSG/PIB i,t: ratio of government consumption of country i during the year $t$.

\subsection{Regression Techniques and Data}

Panel data regressions are used in the present study which covers the period 1988-2008. One of the advantages of panel data regressions is that they permit to control three types of factors: those that vary between the individuals, but do not vary with time, those that could cause an omission bias if one did not take them into account, those that are unobservable or non available and cannot be included in the regression. The information is collected in the World Bank database with an interval of 2 years for each of the 32 countries. This permits us to have 11 observations by country and 352 observations in all. The regressions were based on three groups of countries: the first is made up of the 32 countries of the sample, the second of 21 countries having access to the sea and the last of 11 landlocked countries. For every group of countries, we estimated the model using the ordinary least squares method under the hypothesis of a uniform behavior of the countries in time. This means that the fixed effects of the model are invariant and are identical between the countries. The hypothesis of a homogeneous panel or a model with common effects is made. The test of Fisher shows that the model is globally significant for every group of country.

\section{Results}

The tables below present the main results of the study. In table 1 are presented the results of the set of the 32 countries of the sample. For the set of the 32 countries of the sample, one perceives that FDIs have a positive impact on the economic growth of Sub-Saharan African countries. The coefficient of the variable FDI is positive and significant at $1 \%$ level. The case is the same for the variable domestic investments. As for the variable commercial opening, it is positive and significant at $10 \%$ level. The other variables like the rate of primary schooling, proxy of human capital, the rate of inflation and the exchange rate have positive coefficients, but are 
insignificant.

Table 1. Results of the regressions on the entire set of Sub-Saharan African countries

Hausman Specifications test

Test: Ho: difference in coefficients not systematic

$\operatorname{chi} 2(7)=(b-B){ }^{\prime}\left[\left(V \_b-V \_B\right)^{\wedge}(-1)\right](b-B)=16.28$

Prob $>$ chi2 $=0.0226$

Results of the Random Effects Model

\begin{tabular}{llll}
\hline Dependent variable: TCPIB & & \\
\hline Explanatory variables & Coefficients & Standard errors & $\mathrm{p}$-value $(\mathrm{p}>\mathrm{z})$ \\
LOGPOP & -.0743006 & .2717954 & 0.785 \\
IDO/PIB & .1815166 & .0448992 & $0.000^{* * *}$ \\
FDI/PIB & .278394 & .075177 & $0.000^{* * *}$ \\
TSP & .0087858 & .0113582 & 0.439 \\
INFLATION & .027408 & .0849738 & 0.747 \\
OUVERTCOM & .3272382 & .1263745 & $0.010^{*}$ \\
EXCHANGE & .0000705 & .000146 & 0.629 \\
CONSG $/$ PIB & -.0459629 & .0485829 & 0.344 \\
Const & -2.639712 & 4.912206 & 0.591 \\
Number of obs $=352$ & & \\
Number of groups $=32$ & & \\
Wald chi2 $(8)=95.40$ & & \\
Prob $>$ chi $2=0.0000$ & & & \\
\hline Notes: $* * *$ Significance at $1 \% ; *$ Significance at $10 \%$. & &
\end{tabular}

Notes: *** Significance at $1 \% ; *$ Significance at $10 \%$.

Table 2 presents the results of the countries having access to the sea whereas those related to the landlocked countries are contained in table 3 .

Table 2. Regression results for the countries having access to the sea

Hausman Specifications test

Test: Ho: difference in coefficients not systematic

$\operatorname{chi} 2(7)=(b-B)^{\prime}\left[\left(V_{-} b-V \_B\right)^{\wedge}(-1)\right](b-B)=20.05$

Prob $>$ chi2 $=0.0055$

(V_b-V_B is not positive definite)

Results of the Random Effects Model

\begin{tabular}{llll}
\hline Dependent variable: TCPIB & & & \\
\hline Explanatory variables & Coefficients & Standard errors & $\mathrm{p}$-value $(\mathrm{p}>\mathrm{z})$ \\
LOGPOP & -.1172548 & .3142106 & 0.709 \\
IDO/PIB & .1935294 & .0538705 & $0.000^{* * *}$ \\
FDI/PIB & .3772243 & .090685 & $0.000^{* * *}$ \\
TSP & -.0009287 & .0160499 & 0.954 \\
INFLATION & .0956364 & .1094751 & 0.382 \\
OUVERTCOM & .1979291 & .1312057 & 0.131 \\
EXCHANGE & .0000485 & .0001541 & 0.753 \\
CONSG/PIB & -.0620299 & .0565459 & 0.273 \\
Const & -1.518463 & 5.89763 & 0.797 \\
Number of obs $=231$ & & & \\
Number of groups $=21$ & & & \\
Wald chi2 $(8)=80.93$ & & & \\
Prob $>$ chi $2=0.0000$ & & & \\
\hline
\end{tabular}

Note: $* * *$ Significance at $1 \%$.

For every group of countries, the results of the Hausman test led us to choose the random effects model. The fact that a random effects model is chosen to the detriment of a fixed effects model shows the simultaneous influence of the global features of the countries of every group and specific features to each of the countries in the process of economic growth. 
Table 3. Regression results for landlocked countries

Hausman Specifications test

Test: Ho: difference in coefficients not systematic

$\operatorname{chi} 2(7)=(b-B)^{\prime}\left[\left(V_{-} b-V_{-} B\right)^{\wedge}(-1)\right](b-B)=19.86$

Prob $>$ chi2 $=0.0059$

(V_b-V_B is not positive definite)

Results of the Random Effects Model

Dependent variable: TCPIB

Explanatory variables

LOGPOP

IDO/PIB

FDI/PIB

TSP

INFLATION

OUVERTCOM

EXCHANGE

CONSG/PIB

Const

Coefficients

.099409

.1961885

.0208515

$-.0022998$

.0157616

5.294494

$-.0003806$

$-.1587146$

$-4.036639$

Number of obs $=121$

Number of groups $=11$

Wald chi2 $(8)=91.33$

Prob $>$ chi $2=0.0000$

Notes: $* * *$ Significance at $1 \%$; Significance at $10 \%$.

As concerns global features, the different tables results indicate that the panel data model is globally significant at $1 \%$ level (Prob $>$ chi $2=0.0000$ ) for the three groups of countries. With regard to the quality of the fitness, it is $22,5 \%$ for the set of the 32 countries, $28 \%$ for the countries having access to the sea and better again of $43,65 \%$ for the landlocked countries. To this effect, it is fairly acceptable. It means that other variables exist, different from those used in the models that explain the rate of economic growth. These variables could be for example the natural resources, the banking intermediation rate or the privatization of the public corporations.

The results of the Dicker Fuller stationnarity tests in table 4 below show that all utilized variables are stationary of order one.

Table 4. Unit root test: Augmented Dickey - Fuller test (ADF)

\begin{tabular}{lllll}
\hline Variable & ADF & Probability ADF & Order of integration & Decision of the stationarity level \\
\hline TCPIB & 92.3103 & $0.0118(* *)$ & $\mathrm{I}(0)$ & Yes \\
IDO/PIB & 114.439 & $0.0001\left(^{* * *}\right)$ & $\mathrm{I}(0)$ & Yes \\
OUVERTCOM & 119.524 & $0.0000(* *)$ & $\mathrm{I}(0)$ & Yes \\
FDI/PIB & 153.948 & $0.00000(* * *)$ & $\mathrm{I}(1)$ & Yes \\
TSP & 127.442 & $0.0000(* *)$ & $\mathrm{I}(0)$ & Yes \\
INFLATION & 87.8793 & $0.0255(* *)$ & $\mathrm{I}(2)$ & Yes \\
EXCHANGE & 100.588 & $0.0024(* *)$ & $\mathrm{I}(0)$ & Yes \\
CONSG/PIB & 117.472 & $0.0001\left(^{* * *}\right)$ & $\mathrm{I}(0)$ & Yes \\
LPOP & 80.7833 & $0.0766(*)$ & $\mathrm{I}(0)$ & Yes \\
\hline
\end{tabular}

Notes: $* * *$ Significance at $1 \% ; * *$ Significance at $5 \% ; *$ Significance at $10 \%$.

When one makes a comparison between the results of the landlocked countries and those of the countries having access to the sea, one perceives that the coefficient of the variable FDI is positive for the two groups of countries, but significant only for the countries having access to the sea. The case is the same for the variable domestic investments. One can explain these results by the fact that the landlocked countries attract less FDI compared to the countries having access to the sea.

The specificities of the countries in the explanation of growth are appreciated by the sigma_u and the R2 between. For every group of countries, the sigma_u is greater than 0 . It is even greater than 1 for the landlocked countries. This result shows that the factors not included in the model and having an impact on economic growth are related to the specificities of the countries of the sample. The R2 between informs us on the contributions of the variable effects of each country. It is equal to $58.66 \%$; $63.56 \%$ and of $49.18 \%$ respectively for the set of the countries, for those having access to the sea and for the landlocked countries. This means that the different 
variables take values that differ from one country to the other. This can be seen in the variation in the growth rate that is positive in some countries and negative in others, on the variation of other variables like the rate of schooling, commercial openness and the domestic investment rate.

\section{Discussion}

The objective of the present study was to evaluate the effects of FDIs economic growth in Sub-Saharan Africa through panel data regressions with a comparison between landlocked countries and those having access to the sea. The results show the existence of a positive impact of FDIs on economic growth on the whole, but with a comparative advantage for the countries having access to the sea in relation to the landlocked countries. This is why the recommendations are about measures capable of encouraging the influx of FDIs on the one hand in the countries of this part of the continent and on the importance for the landlocked countries to invest in the development of the infrastructure on the other hand.

\subsection{The Recommendations in Favor of the Attractiveness to FDI}

The data in Table 5 show dynamism of countries in our sample in terms of FDI attraction in the past two decades. Flows increased from U.S. \$ 258.3 million in 1995 to 11400.15 million dollars in 2003 . There has been a $21.6 \%$ decline between 2003 and 2005. This decline in flows is primarily dependent to the situation of Angola, Chad and Swaziland which registered negative flows in 2005. Countries that were more attractive are Angola, Nigeria, Republic of Congo, and Equatorial Guinea. These countries are not only oil producers, but are also opened to sea. Landlocked countries are generally less attractive except those that exploit oil and minerals such as Chad and Niger in the years 2006 and 2009.

Table 5. Evolution FDI inflows in the 32 countries of the survey (in $10^{3} \$$ US)

\begin{tabular}{|c|c|c|c|c|c|c|c|}
\hline Countries & 1995 & 1997 & 2000 & 2003 & 2005 & 2008 & 2009 \\
\hline Angola & 472427 & 411660 & 878620 & 3504701 & -1303836 & 1678971 & 2205298 \\
\hline Benin & 13329 & 27015 & 59736 & 44731 & 53043 & 169834 & 134285 \\
\hline Botswana & 70413 & 100109 & 57176 & 770536 & 492380 & 902413 & 824081 \\
\hline Burkina Faso & 9816 & 9765 & 23219 & 30831 & 31967 & 152465 & 105204 \\
\hline Burundi & 1981 & 0.1 & 11683 & 4.618 & 584 & 3833 & 348.7 \\
\hline Cameroon & 7292.4 & 78335.6 & 158801.5 & 336267.8 & 234006.5 & -24198 & 668329.4 \\
\hline Central A. R. & 6200.5 & 1497.4 & 842.7 & 22195.4 & 32419 & 117119 & 42250.5 \\
\hline Tchad & 32611.5 & 44293.9 & 115172.4 & 712663.4 & -99342.5 & 233583.8 & 461808 \\
\hline Congo, RDC & -22350 & -44350 & 72000 & 391300 & - & 1726800 & 663800 \\
\hline Congo, Rep. & 125019 & 79171.5 & 165904.4 & 323124.3 & 513585.5 & 2483223.7 & 2083496 \\
\hline Equatorial G. & 126924 & 53451.5 & 154499.5 & 689779.7 & 769146 & -793872.3 & 1636219.6 \\
\hline Gabon & -314523.6 & -311296 & -42626.4 & 157986.8 & 242335 & 209019.5 & 32826 \\
\hline Ethiopia & 14140 & 288490 & 134640 & 465000 & 265111.6 & 108537.5 & 221459.5 \\
\hline Ghana & 106500 & 81800 & 165900 & 136751 & 144970 & 2714916.3 & 1423906.8 \\
\hline Guinea & 769 & 17301 & 9942 & 78966 & 105000 & 381880 & 49820 \\
\hline Kenya & 42289 & 62096.8 & 110904.5 & 81738 & 21211.6 & 95585.6 & 116257.6 \\
\hline Madagascar & 9710 & 14005.4 & 82952.5 & 12874 & 85444 & 1169359.7 & 1066058.4 \\
\hline Malawi & 5643 & 14868.7 & 25999.9 & 83151.2 & 38143.3 & 175774.7 & 75817.6 \\
\hline Mali & 111429 & 62986 & 82439.5 & 132260.7 & 188138.3 & 131677.7 & 718457.9 \\
\hline Mauritius & 18692.8 & 55277.8 & 265641.2 & 62630.665 & 41776.996 & 377724.7 & 256680 \\
\hline Mozambique & 45000 & 64400 & 139200 & 336698.8 & 107853.3 & 591619.8 & 892502.8 \\
\hline Niger & 7188 & 18171 & 8437 & 14912 & 43976 & 340427 & 815339.2 \\
\hline Nigeria & 1079271 & 1539445 & 1140137.6 & 2005390 & 4982533.9 & 8196606.6 & 8554840 \\
\hline Rwanda & 2212.2 & 2598.5 & 8319 & 4655.6 & 8030 & 103350 & 118671 \\
\hline Senegal & 31673.9 & 176017.4 & 62937.4 & 52494.8 & 44588.4 & 397632.6 & 331079 \\
\hline Seychelles & 45884.3 & 53398.6 & 24326.9 & 58425.5 & 85879.6 & 129454.5 & 118480.8 \\
\hline Tanzania & 119936.6 & 157885 & 463400.8 & 364258.8 & 935520 & 400047 & 414544.6 \\
\hline Swaziland & 51756 & -15313.9 & 90658 & -60903.8 & -45850.3 & 105729.3 & 65705.8 \\
\hline Togo & 26168569 & 20999903 & 41921341 & 33733636 & 76992328 & 23883150 & 48531693 \\
\hline Uganda & 121200 & 175000 & 160700 & 202192.5 & 379808.3 & 728860.9 & 841570.8 \\
\hline Zambia & 97000 & 207400 & 121700 & 347000 & 356940 & 938600 & 694800 \\
\hline Zimbabwe & 117700 & 135100 & 23200 & 3800 & 102800 & 51600 & 105000 \\
\hline Total & 2583308 & 3581583 & 4818388.6 & 11400153.5 & 8935158.2 & 24022462.4 & 25787475 \\
\hline
\end{tabular}

Source: World Development indicators 2011. 
This classification based only on the absolute flux and that does not take into account the size of the economy is less significant. The classification of FDI relative to GDP (table 6) shows that in 2006 the attraction of FDI is still dominated by the oil exporting countries. Republic of Congo and Chad are leaders with each FDI / GDP ratio above $10 \%$. The third place occupied by the Democratic Republic of Congo is explained by FDI flows for the exploitation of minerals held by this huge country. The same explanation applies to the Niger in 2009, which ranks second after the Republic of Congo with a ratio of $15.51 \%$.

Table 6. Evolution of FDI/GDP ratio in sub-Saharan African countries of our sample

\begin{tabular}{|c|c|c|c|c|c|}
\hline \multirow{2}{*}{$\begin{array}{l}\text { 1990-1999 (annual mean) } \\
\text { Countries }\end{array}$} & \multirow[b]{2}{*}{$\%$} & \multicolumn{2}{|l|}{2006} & \multicolumn{2}{|l|}{2009} \\
\hline & & Countries & $\%$ & Countries & $\%$ \\
\hline Equatorial Guinea & 32.07 & Congo & 12.7 & Congo & 21.71 \\
\hline Angola & 8.01 & Chad & 11.11 & Niger & 15.51 \\
\hline Seychelles & 6.81 & Congo (RDC) & 6.55 & Seychelles & 14.08 \\
\hline Swaziland & 5.27 & Equatorial Guinea & 9 & Equatorial Guinea & 13.37 \\
\hline Nigeria & 4.07 & Nigéria & 6.11 & Madagascar & 12.55 \\
\hline Zambia & 3.48 & Togo & 6.07 & Mozambique & 9.22 \\
\hline Mozambique & 2.69 & Zambia & 4.4 & Mali & 8.01 \\
\hline Ouganda & 1.75 & Angola & 4.3 & Botswana & 7.14 \\
\hline Cote d'Ivoire & 1.52 & Seychelles & 4.24 & Chad & 6.51 \\
\hline Ghana & 1.28 & Tanzania & 4.22 & $\mathrm{RDC}$ & 5.92 \\
\hline Zimbabwe & 1.28 & Mozambique & 4.13 & Ghana & 5.48 \\
\hline Tanzania & 1.26 & Ouganda & 2.96 & Ouganda & 5.32 \\
\hline Malawi & 1.25 & Swaziland & 2.57 & Zambia & 5.42 \\
\hline Gabon & 1.25 & Malawi & 2.31 & Nigeria & 5.07 \\
\hline Mali & 1.08 & Ghana & 1.98 & Cameroon & 3.01 \\
\hline Senegal & 1.07 & Guinea & 1.98 & Mauritius & 2.9 \\
\hline Togo & 0.99 & Senegal & 1.4 & Senegal & 2.59 \\
\hline Benin & 0.87 & Mali & 1.21 & Rwanda & 2.25 \\
\hline Chad & 0.86 & Madagascar & 1.21 & Swaziland & 2.22 \\
\hline Mauritius & 0.85 & Côte d'Ivoire & 1.12 & Central A. R. & 2.13 \\
\hline Éthiopia & 0.78 & Benin & 1.1 & Benin & 2.04 \\
\hline Guinea & 0.69 & Ethiopia & 1.03 & Tanzania & 1.94 \\
\hline Madagascar & 0.61 & Kenya & 0.67 & Zimbabwe & 1.79 \\
\hline Burkina F. & 0.56 & Botswana & 0.6 & Côte d'Ivoire & 1.65 \\
\hline Niger & 0.41 & Niger & 0.59 & Malawi & 1.6 \\
\hline Botswana & 0.25 & Mauritius & 0.58 & Togo & 1.53 \\
\hline Kenya & 0.2 & Burkina F. & 0.4 & Angola & 1.3 \\
\hline Congo & 0.19 & Burundi & 0.4 & Burkina F. & 1.26 \\
\hline Central A. R. & 0.16 & Central A. R. & 0.23 & Guinea & 1.19 \\
\hline Cameroon & 0.1 & Zimbabwe & 0.19 & Ethiopia & 0.69 \\
\hline
\end{tabular}

Source: World Development indicators 2011.

It should be noted that for several decades, Western multinationals have monopolized FDI in Africa. They are mostly concentrated on the oil and mining sectors. This lack of diversification has significantly delayed the development of African countries. The graph below shows that China offers an opportunity to diversify FDI in Africa. Hope in the diversification of FDI in Africa comes from China as shown in the graph below. 


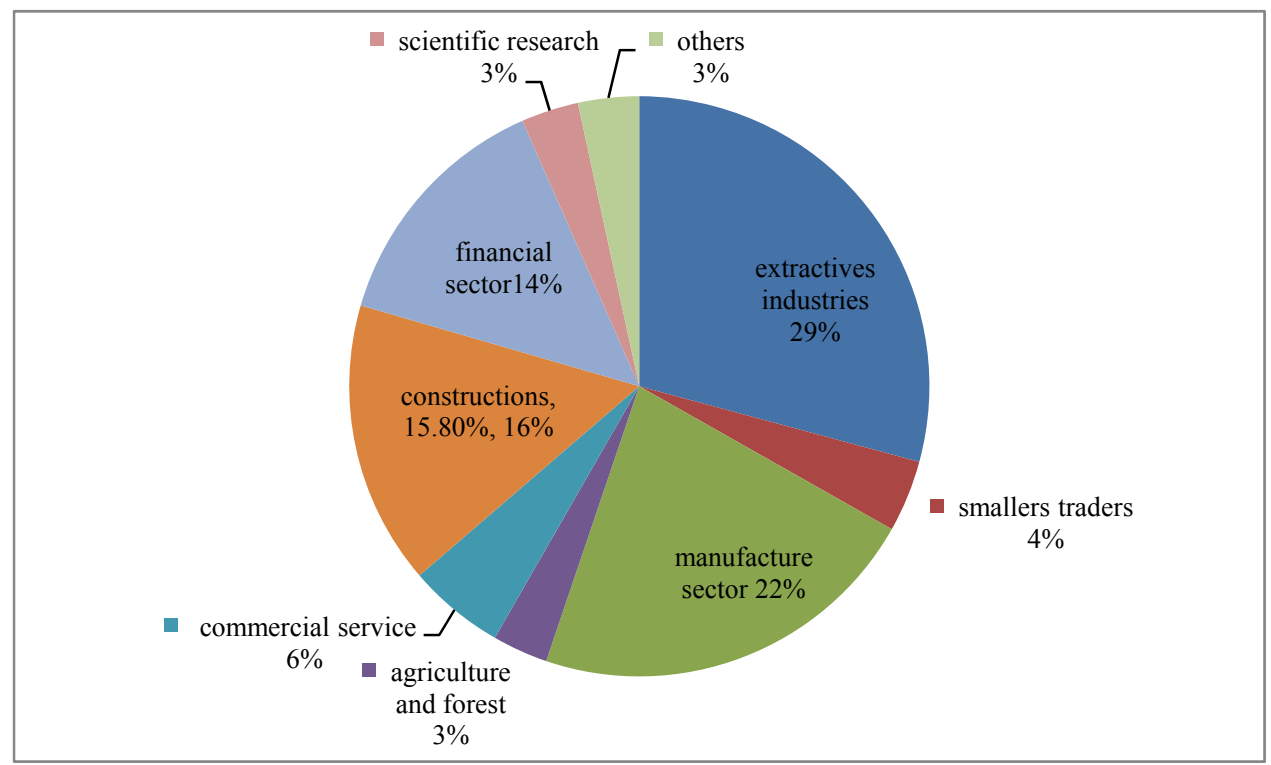

Figure 1. Repartition of China's FDI in African countries in 2009

Source: FMI (2011).

It can indeed be noted that Chinese firms are involved in key development sectors such as construction, the financial sector and the manufacturing sector. If it is determined that African leaders should encourage foreign investors to direct their capital in several sectors of the economy, we must also recognize that many actions are to be implemented on the institutional and governance domain.

The regulatory framework of FDI in Sub-Saharan Africa is characterized on the political level by the democratization process which triggered in the beginning of the 90s. Although there has been relative stability in some of the States, others unfortunately witnessed civil wars (Liberia, Burundi, Rwanda, Central African Republic, Republic of Congo, Ivory Coast, etc). According to Singh and Jun (1995 and 1996), the socio-political instability is a complex phenomenon and constitutes a hindrance to the attraction of FDI. This is why the Sub-Saharan African countries should put in place strong democratic institutions. The progressive withdrawal of the state from the productive sector resulted in the privatization of the public corporations in many countries. This process that covers the enterprises of all sectors of the economy spread itself to many countries of Sub-Saharan Africa. Sader (1995), Basu and Srinivasan (2002), show that the efforts of privatization attract FDI through the direct sales of the enterprises. This process should continue to permit to the local enterprises to benefit from the know-how of foreign investors. With regard to the rates of schooling, they are considered as proxy of the qualification of the manpower. Education is regarded as a means to prepare and to adjust to the permanent changes of the environment and working conditions (Word Bank, 1995). In Sub-Saharan Africa, if the rates of schooling are relatively high in the primary level, they are low in the secondary. This explains the low level of qualification of the manpower. It is why the Sub-Saharan African countries should center growth in middle and long term on education, through the construction of infrastructures, the adaptation of the teaching syllabus to international norms and the recruitment of more qualified teachers. Concerning the gains in efficiency, many countries concluded bilateral treaties and signed multilateral agreements with international organizations. The harmonizations of the investment codes, as well as measures to encourage investments have intensified. Many countries of East and South Africa adhered to the Cross Border Initiative (CBI) while adopting a common code of facilitation of investments. Some similar protocols were finalized in the other regions of Sub-Saharan Africa: Economic and Monetary Community of Central African States (EMCCAS); West African Economic and Monetary Union (WAEMU), and the Southern African Development Community (SADC). The ratification of the "OHADA" treaty (Organization for the harmonization of Business Law) by all States of the franc zone constitutes a hope for the reinforcement of integration. A study by Blomstrôm and Kokko (1997) in the countries of MERCOSUR shows that a well conducted integration stimulates FDI. For the Sub-Saharan African countries, to sign the agreements only is not sufficient, what is important is to apply them. In the countries of the EMCCAS for example, the notion of integration, free circulation of goods and people is still hindered by many factors like the selfishness of some leaders that results in acts of xenophobia, the insufficiency of the communication infrastructures between the countries, etc. 


\subsection{The Development of the Transportation Infrastructures}

The state of the transportation infrastructures in Africa remains faltering. The road remains the most utilized means of transportation. However, its density is of $6.84 \mathrm{~km}$ for $100 \mathrm{~km} 2$ against $12 \mathrm{~km}$ for $100 \mathrm{~km} 2$ in Latin America and $18 \mathrm{~km}$ for $100 \mathrm{~km} 2$ in Asia. The length of the covered network is only of $24.56 \%$ of the total network against $64.1 \%$ for the north African sub-region. With regard to the African railway network, it was estimated at $89380 \mathrm{~km}$ in 2005 (Nations Unies, 2007), giving a weak density of 2,96km for $100 \mathrm{~km} 2$. In addition, the management of the network was characterized in many countries by a heavy bureaucracy and a weak profitability. It is necessary to add that many African countries as Burundi, Cape - Verde, Comoros, Gambia, Guinea Bissau, Equatorial Guinea, Niger, Central African Republic, Rwanda, Seychelles, Somalia, Chad, etc were still unfortunately destitute of this means of transportation just before the year 2007. As to the maritime transportation, the 53 African countries counted 80 seaports in 2004. These ports are under equipped compared to those of the other developing countries. They are exposed to a certain number of problems of which those of pollution, erosion, insufficiency of measures of facilitation and technical capacities. Moreover, $80 \%$ of African ships are more than 15 years of age against a world average of $15 \%$. These different problems compromise the African harbor productivity. The situation of the air transport is even worse. In 2004, Africa counted 117 international airports and 500 domestic airports that are characterized by a strong deterioration of the tracks due to the lack of maintenance, of the old facilities that do not correspond anymore to the international norms, of the insufficient safety measures and security. This poor nature of infrastructure that constitutes a hindrance to the circulation of the men and goods is not likely to attract the foreign investors. The situation of the landlocked countries is even more compromising. That is why these countries should put in place strategies of development of infrastructures. Numerous studies show the existence of a positive relation between FDI and infrastructures (Asiedu 2002). Finally, the Sub-Saharan African countries should make considerable efforts in the direction of improving the attractiveness of foreign direct investments in order to cover their deficit in funds. At the same time, strategies in favor of the development of the transportation infrastructures should be put in place. For these efforts to produce the expected results, the questions of governance that are relevant to all strategies should be in the center of the preoccupations of African leaders.

\section{References}

Abdur, C., \& Mavrotes, G. (2003). FDI and growth: what causes what? WIDER Conference, Helsinki, 6-7 September.

Aghion, P., \& Howitt P. (1992). A Model of Growth Through Creative Destruction. Econometrica, 60(2), 323-351. http://dx.doi.org/10.2307/2951599

Asiedu, E. (2002). On the Determinants of Foreign Direct Investment to Developing Countries: Is Africa Different? World Development, 30(1), 107-118. http://dx.doi.org/10.1016/S0305-750X(01)00100-0

Baro, R. J. (1990). Government Spending in a Single Model of Endogenous Growth. Journal of Political economic, 98(5), Part II, S103-S125.

Basu, A. K. S. (2002). Foreign Direct Investment in Africa: Some cases Studies. FMF working paper, February.

Berthélémy, J. C., \& Démurger, S. (2000). Foreign Direct Investment and Economic Growth: Theoretical Issues and Empirical Application to China. Review of Dovelopment Economics, 4(2), 140-155. http://dx.doi.org/10.1111/1467-9361.00083

Blomström, M. R. E., Lipsey, \& Zejan, M. (1994). What explains developing countries growth? NBER Working paper, 4132.

Blomström, M., \& Kokko. (1997). Regional Integration and Foreign Direct Investment: A conceptual Framework and Three Cases. Policy Research Working paper, No 1750.

Borensztein, E., De Gregorio, J., \& Jong-Wha, L. (1995). How does Foreign Direct Investment affect Economic growth? National Bureau of Economic Research, Cambridge, MA 02138, March.

Bosworth, B., \& Collins, S. M. (1999). Capital Flows to Developing Economies: Implications for Saving and Investment. Meeting Draft (revised).

Catin, M., Ghio, S., \& Van, H. (2002). Investissements Directs Étrangers, diffusion technologique et concentration spatiale dans les pays en développement. Région et Développement, 16, 55-82.

CNUCED. (1999). Foreign Direct Investment in Africa: Performance and Potential. United Nations.

Cockcroft, \& Riddell. (1991). Foreign Direct Investment in Sub-Saharan Africa. WPS 619 Washington, DC, 
World Bank.

De Mello, L. R. (1996). Foreign Direct Investment, International Knowledge transfers, and Endogenous Growth. Time series Evidence MIMEO, Department of Economics, University of Kent.

Duming, J. H. (1993). Multinational Enterprises and the Global Economy. ESSEX: Addison- wesley Publishers.

Fung, K. L., Hitomi, L., \& Tong, S. (2002). Foreign Direct Investment in China: policy, Trend and Impact. International Conference on China's economic in the 21st Century, June 24-25, Hong- Kong.

IMF. (2011). Perspectives économiques régionales: Afrique subsaharienne, maintenir la croissance. International Monetary Fund.

Kim, C. H. (1985). The Concept and social position of the "Management Elite", in contemporary Kenya with special reference to Africanisation. Working Paper, n. 431, Institute of Development Studies, University of Nairobi.

Knodler, H., \& Albertshausser, U. (2001). Globalisation, Foreign Direct Investment and Regional Development Perspectives: Empirical Results for West German Regions. HWWA Discussion Paper, № 117.

Lucas, R. (1988). On the Mecanics of Economic Development. Journal of Monetary Economics, 22(1), 3-42. http://dx.doi.org/10.1016/0304-3932(88)90168-7

Moran, T. (1999). Foreign Direct Investment and Development. Washington, DC, Institute for International Economics.

Nair-reichert, U., \& Weinhold, D. (2001). Causality Tests for Cross-Country panels: A new look at FDI and Economic Growth in Developing countries. Oxford Bulletin of economics and Statistics, 63(2), 153-171. http://dx.doi.org/10.1111/1468-0084.00214

Nations Unies. (2007). Situation des transports en Afrique. Commission Economique pour l'Afrique; document de travail, Addis-Abeba.

Nauro, F. C., \& Kinoshila, Y. (2002). Foreign Direct Investment as technology transferred: some panel evidence from the transition Economics. William Davidson Working Paper, $\mathrm{N}^{\circ} 438$ January.

Nzomo, D. (1971). Occupational Kenyanisation in the Private Sector. Staff Paper n. 108, Nairobi, Institute of Development studies.

Olakounlé, Y. G. (2004). Les investissements directs étrangers sont-ils réellement un moteur de la croissance dans les pays en développement? les résultats mitigés d'une analyse empirique. Revue Canadienne d'études du développement, $X X V(2), 275-291$.

Pigato, M. (2000). Foreign Direct Investment in Africa: Old told and new evidence. The world Bank, January.

Rodrik, D. (1999). The New Global Economy and Developing Countries: Making Openness Work. Policy Essay 24, Overseas development council, Washington D.C.

Romer, P. M. (1986). Increasing Returns and Long-Run Growth. Journal of Political Economy, 94(5). http://dx.doi.org/10.1086/261420

Romer, P. M. (1990). Endogenous Technological Change. Journal of Political Economy, 98(5). http://dx.doi.org/10.1086/261725

Sader, F. (1995). La privatisation des entreprises publiques et l'investissement étranger dans les pays en développement, 1988-93. FIAS, no5F.

Schubert, K. (2000). la croissance. Chapitre 11 de l'ouvrage Analyse macro économique Édité par Jean Olivier Hairault, la Découverte, Paris.

Singh, H., \& Jun, K. W. (1995). Some New Evidence on Determinants of Foreign Direct Investment in Development countries. Policy Research Working Paper, No 1531, November.

Singh, H., \& Jun, K. W. (1996). The Determinants of Foreign Direct Investment in Development Countries. Translational corporations, 5(2).

Solow, R. M. (1956). A Contribution to the Theory of Economic growth. Quarterly Journal of Economics, 70(1), 65-94. http://dx.doi.org/10.2307/1884513

Swan, T. W. (1956). Economic Growth and capital Accumulation. Economic Record, November, 334-361. http://dx.doi.org/10.1111/j.1475-4932.1956.tb00434.x 
Toufik, S., \& Bouoiyour, J. (2002). Interaction entre investissements directs étrangers, productivité et capital humain: cas des industries manufacturières marocaines. Document de travail, septembre.

World Bank. (1995). Priorities and Strategies for education. A World Bank Review, development in Practice. Washington D.C.

Xiaoying, L., \& Xiaming, L. (2005). Foreign Direct Investment and Growth: An Increansingly Endogenous relationship. World Development, 33, 393-407. http://dx.doi.org/10.1016/j.worlddev.2004.11.001 